\title{
IN VITRO ISOLATION AND MOLECULAR CHARACTERIZATION OF AN EHRLICHIA CANIS STRAIN FROM SÃO PAULO, BRAZIL
}

\author{
Daniel M. Aguiar ${ }^{1,3 *}$; Mitika K. Hagiwara ${ }^{2}$; Marcelo B. Labruna ${ }^{3}$ \\ 'Departamento de Clínica Médica Veterinária, Faculdade de Agronomia e Medicina Veterinária, Universidade Federal de Mato \\ Grosso, Cuiabá, MT, Brasil; ²Departamento de Clinica Médica Veterinária, Faculdade de Medicina Veterinária e Zootecnia, \\ Universidade de São Paulo, São Paulo, SP, Brasil; ${ }^{3}$ Departamento de Medicina Veterinária Preventiva e Saúde Animal, \\ Faculdade de Medicina Veterinária e Zootecnia, Universidade de São Paulo, São Paulo, SP, Brasil
}

Submitted: June 18, 2007; Returned to authors for corrections: February 22, 2008; Approved: July 05, 2008.

\begin{abstract}
An Ehrlichia canis isolate was obtained from an naturally infected dog exhibiting clinical signs of ehrlichiosis in São Paulo Municipality, state of São Paulo, Brazil. The isolate was characterized by PCR and DNA sequencing of portions of the ehrlichial genes $d s b, 16 \mathrm{SrRNA}$, and $p 28$. Partial $d s b$ and $16 \mathrm{~S}$ rRNA sequences were identical to three and five other $E$. canis strains, respectively, from different countries and continents (including North America, Africa, Asia and Europe). Conversely, the $p 28$ partial sequence for this E. canis (São Paulo) differed by 1,2, and 2 nucleotides from the corresponding sequences of the E. canis strains Jake (from USA), Oklahoma (USA), and VHE (Venezuela), respectively. The results in this study indicate that $E$. canis is the only recognized Ehrlichia species infecting dogs in Brazil.
\end{abstract}

Key-words: Ehrlichia canis, Dog, Molecular Characterization, Ehrlichiosis.

\section{INTRODUCTION}

Ehrlichia canis is the primary etiologic agent of canine monocytic ehrlichiosis (CME), which is recognized as the most prevalent tick-borne disease affecting dogs in Brazil (1). The widespread distribution of the tick vector (Rhipicephalus sanguineus) in most urban areas of Brazil, combined with a persistent infection of $E$. canis in dogs, and lack of effective immunity to $E$. canis, contribute to the high prevalence of CME in the country $(1,2,7,14)$.

CME in Brazil was first described in 1973 by Costa et al. (8). Recent local data suggest that $20-30 \%$ of dogs admitted to veterinary hospitals from various areas had antibodies reacting with $E$. canis antigens and/or had detectable $E$. canis DNA $(6,9,13,21)$. Despite the widespread distribution of $E$. canis in Brazil, only two isolates have been propagated in the laboratory: one from Rio de Janeiro city (22) and another from Jaboticabal County, state of São Paulo $(2,15)$. Both isolates were established in a canine monocyte cell line (DH82 cells); however, only one isolate (Jaboticabal) has been molecularly characterized.

E. canis appears to be highly conserved among geographically dispersed isolates. Aguirre et al. (3) described a high identity of $16 \mathrm{~S}$ rRNA gene sequences in isolates from the United States, Israel, Japan and Venezuela. McBride et al. (17) revealed that a $p 28$ gene from seven different NorthAmerican isolates was identical. In addition, partial sequences of the $d s b$ gene of isolates from Cameroon, Brazil, and United States were identical $(2,19)$. In the present study, we report a new isolate of E. canis from a dog in Brazil, which has been established in cell culture. Additionally, we performed a partial molecular characterization of the isolate.

\section{MATERIALS AND METHODS}

\section{Case report}

A 7-year old male Labrador retriever was admitted to the São Paulo University Veterinary Hospital with recurrent history

*Corresponding Author. Mailing address: (D.M.A.) Departamento de Clínica Médica Veterinária, Universidade Federal de Mato Grosso, Avenida Fernando Correa da Costa s/n, Bairro Coxipó, Cuiabá, MT, Brasil, CEP 78060-900. Fone: (65) 3615-8625. E-mail: danmoura@ufmt.br 
of anorexia, apathy, bloody diarrhea and tick infestation. Based on a previous clinical diagnosis of CME, the dog had been treated with doxycycline $(10 \mathrm{mg} / \mathrm{Kg}$ daily for 3 weeks $)$ and imidorcarb dipropionate $(5 \mathrm{mg} / \mathrm{Kg}$,two doses with 15 days interval) 20 days before the appearance of clinical symptoms. The dog was normal upon physical examination. Hematological abnormalities were anemia [hematocrit: $33 \%$ (reference values: 37 - 55\%); low erythrocytes: $4.7 \times 10^{6} / \mathrm{mm}^{3}$ (reference values: 5.5 - $8.5 \times 10^{6} / \mathrm{mm}^{3}$ )], leucopenia [leukocytes: $4,700 / \mathrm{mm}^{3}$ (reference values: $\left.5,000-10,000 / \mathrm{mm}^{3}\right)$ ], and thrombocytopenia [platelet: $19,000 / \mathrm{mm}^{3}$ (reference values: $200,000-500,000 / \mathrm{mm}^{3}$ )]. Blood was collected in EDTA for PCR, and in heparin for cell culture isolation.

\section{Isolation and cultivation of Ehrlichia spp.}

Heparin-anticoagulated whole-blood was collected aseptically from the jugular vein and processed according to Paddock et al. (20). Briefly, leukocytes were isolated by overlaying the buffy coat on Histopaque 1083 (Sigma Diagnostic, St Louis, Mo.), and the interface containing the leukocyte fraction was collected and resuspended in $5 \mathrm{ml}$ of Dulbecco's Modified Eagle's medium (Sigma Aldrich, St Louis, Mo.) supplemented with $10 \%$ heat-inactivated bovine calf serum (Hyclone Laboratories, Logan, Utah). The leukocyte suspension was transferred to a $25 \mathrm{~cm}^{2}$ flask culture and incubated at $37^{\circ} \mathrm{C}$ in a $5 \% \mathrm{CO} 2$ atmosphere. After $24 \mathrm{hrs}, 2 \mathrm{ml}$ of fresh culture medium was added and the cells harvested $24 \mathrm{hrs}$ later and added to a monolayer of uninfected DH82 cells (provided by Jere W. McBride, University of Texas Medical Branch) in a 25 $\mathrm{cm}^{2}$ flask. The culture was maintained under the same conditions as above, except that the bovine calf serum was reduced to $2.5 \%$, and the culture medium was partially $(20 \%)$ replaced every 2-3 days. Cell cultures were monitored twice a week for presence of morulae by both Diff-Quik staining (Laborclin, Pinhais, PR, Brazil) and presence of ehrlichial DNA using PCR.

\section{DNA extraction from blood and cultured cells}

DNA was extracted from either $200 \mu \mathrm{l}$ of canine blood or from inoculated DH82 cells by the DNA easy Tissue Kit (Qiagen Incorporation, Valencia, Calif) according to the manufacturer's protocol. Each DNA sample was eluted in $100 \mu \mathrm{l}$ of TE buffer and stored at $-20^{\circ} \mathrm{C}$ until use for PCR.

\section{PCR analyses}

Extracted DNA ( $5 \mu 1$ containing 100-200 ng of DNA) from infected cell cultures was used as a template to amplify fragments of ehrlichial $d s b, 16 \mathrm{~S}$ rRNA, and $p 28$ genes. DNA obtained from infected dog blood was used to amplify a fragment of the ehrlichial $d s b$. For the $d s b$ gene, a 409 -bp fragment was amplified with primers DSB-330 (5'-GAT GAT GTC TGAAGA TAT GAAACAAAT-3') and DSB- 728 (5'-CTG CTC GTC TAT TTT ACT TCT TAAAGT-3'), as previously described (10) with some modifications (1). Primers GE2'F2' (5'- GTT AGT GGC AGACGG GTG AGT-3') and HE3 (5'-TAT AGG TAC CGT CAT TAT CTT CCC TAT-3') were used to amplify a 360-bp fragment of the 16S rRNA gene (4,5). Primers 793' (5'-GCA GGA GCT GTT GGT TAC TC-3') and 1330 (5'-CCT TCC TCC AAG TTC TAT GCC-3') were used to amplify a 518-bp portion of the $p 28$ gene (17). PCR products were analyzed by $1.5 \%$ agarose gel electrophoresis stained with ethidium bromide and examined by UV transillumination. To minimize the potential risks for contamination, DNA extraction, PCR, and agarose gel eletrophoresis were performed in physically separate rooms. Positive (DNA extracted from tissue cultured-E. chaffeensis) and negative controls (water) were included in all PCR assays.

\section{Sequence analyses}

PCR amplicons were purified using ExoSAP-IT ${ }^{\circledR}$ (USB, Cleveland, USA) and sequenced directly with both forward and reverse primers of each gene ( $d s b, 16 \mathrm{~S}$ rRNA and $p 28)$ with an automated ABI Prism 310 Genetic Analyser (Applied Biosystens/Perkin Elmer). The BLAST program (National Center for Biotechnology Information, Bethasda, MD) was used to compare $d s b, 16 \mathrm{~S}$ rRNA and $p 28$ sequences in order to determine sequence similarities. Deduced amino acid sequences of DSB and 28-kDa proteins were analyzed by using the BLAST program.

\section{RESULTS}

\section{Isolation and culture from dog blood}

PCR amplification of the ehrlichial $d s b$ gene fragment yielded expected amplicon size in DNA extracted from the dog blood and from the DH82 monolayer 14 days after inoculation with the primary leukocyte culture. On day 21 , ehrlichial morulae were observed within the cytoplasm of cells (1-5\% of infected cells). On day $28,5 \%$ of the cells were infected by visualization of ehrlichial morulae (Fig. 1) and E. canis DNA was detected in the culture. The isolate replicated relatively slowly, reaching $90-100 \%$ of infected DH82 cells only after three months. Subsequently, infected cells were sub cultured to uninfected DH82 cells, and the infection reached $90-100 \%$ in 10 to 14 days. Thereafter, the infected cells were sub cultured several times, reaching $90-100 \%$ infection rates in 7 to 10 days after inoculation. Frozen stocks of infected DH82 cells (left at $-80^{\circ} \mathrm{C}$ for several months) maintained a high infectivity when thawed and added to uninfected DH82 monolayers.

The E. canis isolate, designated São Paulo strain, has been deposited in the Rickettsial Collection of the Laboratory of Parasitic Diseases of the Faculty of Veterinary Medicine, in the University of São Paulo (under M.B.L.), and in the reference collection of the UTMB Rickettsial and Ehrlichial Diseases Research Laboratories (maintained by Jere W. McBride) where they are available upon request. 


\section{Molecular characterization of the ehrlichial isolate}

DNA extracted from infected DH82 cells was used as template for PCR targeting portions of the ehrlichial genes $d s b, 16 \mathrm{~S}$ rRNA, and $p 28$. Expected amplicons were visualized in all reactions. After DNA sequencing, generated sequences (excluding corresponding primer regions) contained 355, 339, and 484-bp for $d s b, 16 \mathrm{~S}$ rRNA, and $p 28$ genes, respectively. Sequences showing highest identity to the Sao Paulo isolate generated sequences were determined by BLAST analyses (Table 1). The isolate exhibited high identity with corresponding sequences of $E$. canis in GenBank, confirming that the isolate was E. canis. Deduced amino acid sequence from partial $d s b$ sequence was $100 \%$ (118/118) identical to E. canis strain Jake, $83.8 \%(99 / 118)$ to E.chaffeensis, $79.6 \%(94 / 118)$ to E. muris, $78.8 \%(93 / 118)$ to Ehrlichia sp strain IOE, $74.5 \%$ (88/118) to E. ewingii, and $72.8 \%$ (86/118) to E. ruminantium. Deduced amino acid sequence from partial $p 28$ sequence was $99.3 \%(160 / 161)$ identical to $E$. canis strain Jake, 98.7\% (159/161) to E. canis strains Oklahoma and VHE, $81.9 \%(132 / 161)$ to $E$. chaffeensis, $72.6 \%(117 / 161)$ to $E$. muris, $63.7 \%(65 / 102)$ to $E$. ewingii, and $58.3 \%(91 / 156)$ to $E$. ruminantium. Partial sequences ( $d s b, 16 \mathrm{~S}$ rRNA and $p 28)$ from E. canis strain São Paulo generated in this study were deposited into GenBank and assigned the nucleotide accession numbers DQ460713, DQ460714, and DQ460715.

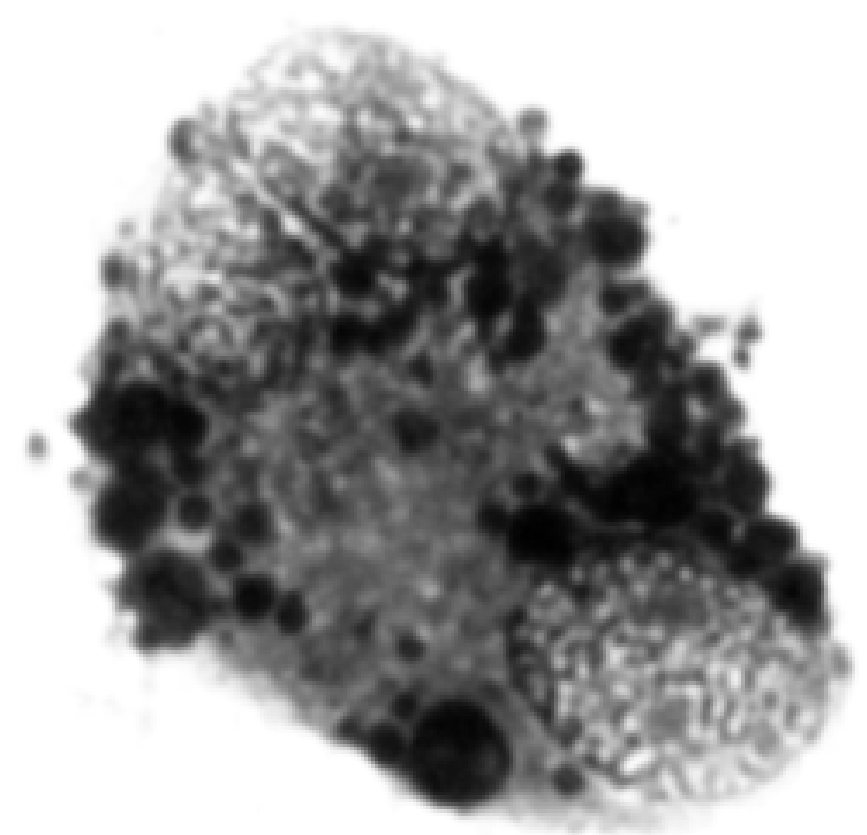

Figure 1. Ehrlichia morulae (São Paulo strain) within DH82 cells stained by Diff-Quik staining (original magnification 100x).

Table 1. Nucleotide sequence identities of the $d s b, 16 \mathrm{~S}$ rRNA and $p 28$ partial sequences of $E$. canis São Paulo strain with available E. canis sequences.

\begin{tabular}{|c|c|c|c|}
\hline \multirow{2}{*}{ Ehrlichia species/ isolate } & \multicolumn{3}{|c|}{ Gene sequence identity \% (number of identical nucleotides / total nucleotides) } \\
\hline & $d s b$ & 16S rRNA & $p 28$ \\
\hline E. canis Jaboticabal & $100(355 / 355)[\mathrm{DQ} 460716]$ & $\mathrm{Na}$ & $\mathrm{Na}$ \\
\hline E. canis $\mathrm{VDE}$ & $\mathrm{Na}$ & $100(339 / 339)[\mathrm{AF} 373613]$ & $\mathrm{Na}$ \\
\hline E. canis VHE & $\mathrm{Na}$ & $100(339 / 339)[\mathrm{AF} 373612]$ & $99.5(482 / 484)[\mathrm{AF} 165815]$ \\
\hline E. canis Florida & $\mathrm{Na}$ & $99.7(338 / 339)[\mathrm{M} 73226]$ & $\mathrm{Na}$ \\
\hline E. canis Jake & $100(355 / 355)[\mathrm{AF} 403710]$ & $100(339 / 339)[\mathrm{CP} 000107]$ & 99.8(483/484) [CР000107] \\
\hline E. canis Oklahoma & $\mathrm{Na}$ & $99.7(338 / 339)[\mathrm{M} 73221]$ & $99.5(482 / 484)$ [AF078553] \\
\hline E. canis Israel & $\mathrm{Na}$ & $99.7(338 / 339)[\mathrm{U} 26740]$ & $\mathrm{Na}$ \\
\hline E. canis Madrid & $\mathrm{Na}$ & $100(339 / 339)[$ AY394465] & $\mathrm{Na}$ \\
\hline E. canis Kagoshima & $\mathrm{Na}$ & $100(339 / 339)[\mathrm{AF} 536827]$ & $\mathrm{Na}$ \\
\hline E. canis Camarões & $100(355 / 355)[\mathrm{DQ} 124254]$ & $\mathrm{Na}$ & $\mathrm{Na}$ \\
\hline E. canis Germishuys & $\mathrm{Na}$ & $99.7(338 / 339)$ [U54805] & $\mathrm{Na}$ \\
\hline E. chaffeensis Arkansas & $81.8(288 / 352)$ [CР000236] & 98.5(334/339) [AF416764] & 78.5 (351/447) [AF479833] \\
\hline E. chaffeensis Jax & 81.8(288/352) [AF403711] & $98.5(334 / 339)$ [ECU86664] & 81.8(384/469) [AF479840] \\
\hline E. ewingii & $76.5(268 / 350)$ [AY428950] & 98.2 (333/339) [AY093439] & $79.7(126 / 158)[\mathrm{AF} 287961]$ \\
\hline E. muris & $79.6(282 / 354)$ [AY236484] & $97.0(329 / 339)[\mathrm{U} 15527]$ & $82.4(281 / 341)[\mathrm{AB} 178804]$ \\
\hline E. ruminantium & $74.0(259 / 350)[\mathrm{AF} 308669]$ & 97.0(329/339) [CR925678] & $75.6(189 / 250)$ [AF368012] \\
\hline Ehrlichia IOE & $79.3(281 / 354)$ [AY236485] & $97.3(330 / 339)[\mathrm{AB} 028319]$ & $82.9(283 / 341)$ [AB178802] \\
\hline
\end{tabular}

Na: not available; [ ] GenBank accession number. 


\section{DISCUSSION}

CME is a very important infectious disease of dogs in Brazil. Anecdotal observations suggest that this agent is widely distributed all over the country, especially in the urban areas, where the tick vector $R$. sanguineus is highly prevalent (14). Isolation and molecular characterization of $E$. canis strain São Paulo demonstrated a high degree of conservation with other E. canis strains that are globally distributed. Partial gene sequences of the E. canis São Paulo showed it to be nearly identical to other characterized $E$. canis strains. In fact, partial $d s b$ and 16S rRNA sequences were identical to three and five other E. canis strains, respectively, from different countries and continents, including North America, Africa, Asia and Europe. However, the $p 28$ partial sequence for E. canis São Paulo differed by 1,2 , and 2 nucleotides from the corresponding sequences of the E. canis strains Jake (from USA), Oklahoma (USA), and VHE (Venezuela), respectively. This result is expected since both $d s b$ and 16S rRNA genes are highly conserved genes, while $p 28$, which encodes for an immunodominat protein, may be under immune pressure of different hosts and thus exhibit some variation $(10,11,18,23)$.

Our $E$. canis isolate derived from a dog that had been treated with doxycycline and imidorcarb for three weeks prior to the recurrence of the clinical CME symptoms. Ineffectiveness of doxycycline for complete elimination of the E. canis infection has been reported in dogs (12). On the other hand, the dog's owner reported tick infestation on the dog during and after the course of antibiotic therapy, what might have favored the recurrence of the disease. Laboratory findings demonstrated low hematological values for all cellular series, resulting in pancytopenia. Notably, platelet count value $\left(19,000 / \mathrm{mm}^{3}\right)$ was much lower than the minimal reference value $\left(200,000 / \mathrm{mm}^{3}\right)$ indicating a severe thrombocytopenia. Based on this clinical and epidemiological history, it is not possible to determine whether recurrence of clinical CME was due to a new infection acquired through infected ticks or the dog harbored chronic form of CME.

The results in this study point out that, currently, E. canis is the only recognized Ehrlichia species infecting dogs in Brazil. Further studies are required to evaluate other $E$. canis isolates from different geographic areas of Brazil, and verify the presence of different Ehrlichia species infecting dogs. For instance, $E$. chaffeensis DNA was recently reported in wild marsh deer (Blastocerus dichotomus) from the eastern part of the state of São Paulo (16).

\section{ACKNOWLEDGMENTS}

We thank J. W. McBride and D. H. Walker (University of Texas Medical Branch) and T. Bronhall for their technical support and thoughtful review of the manuscript. This work was supported by the Fundação de Amparo à Pesquisa do Estado de São Paulo - FAPESP (grants to D.M.A. and M.B.L.) and Conselho Nacional de Desenvolvimento Científico e Tecnológico - CNPq (grants to M.B.L. and M.K.H.)

\section{RESUMO}

\section{Isolamento e caracterização molecular de um isolado de Ehrlichia canis}

Foi obtido um isolado de Ehrlichia canis a partir de um cão naturalmente infectado com sinais clínicos de erliquiose, oriundo do município de São Paulo, SP, Brasil. O isolado foi caracterizado molecularmente pela PCR e seqüenciamento de porções dos genes $d s b, 16 \mathrm{~S}$ rRNA, e $p 28$. A seqüência parcial dos genes $d s b$ e 16Sr RNA apresentaram-se idênticas a três e cinco seqüências respectivamente, de E. canis provenientes de diferentes países e continentes (América do Norte, África, Ásia e Europa). Contrariamente, a seqüência parcial do gene $p 28$ do isolado São Paulo diferiu em um nucleotídeo do isolado Jake (EUA) e dois nucleotídeos dos isolados Oklahoma (EUA) e VHE (Venezuelan Human Ehrlichia - Venezuela). Atualmente, a E. canis é a única espécie de Ehrlichia que acomete cães no Brasil.

Palavras-chaves: Ehrlichia canis, Cão, Caracterização molecular, Erliquiose.

\section{REFERENCES}

1. Aguiar, D.M.; Cavalcante, G.T.; Pinter, A.; Gennari, S.M.; Camargo, L.M.A.; Labruna, M.B. (2007a). Prevalence of Ehrlichia canis (Rickettsiales: Anaplasmataceae) in dogs and Rhipicephalus sanguineus (Acari: Ixodidae) ticks from Brazil. J. Med. Entomol., 44: 126-132.

2. Aguiar, D.M.; Saito, T.B.; Hagiwara, M.K.; Machado, R.Z.; Labruna, M.B. (2007b). Diagnóstico sorológico de erliquiose canina com antígeno brasileiro de Ehrlichia canis. Ciênc. Rural., 37: 796-802.

3. Aguirre, E.; Sainz, A.; Dunner, S.; Amusategui, I.; López, L.; RodríguesFranco, F.; Luaces, I.; Cortés, O.; Tesouro, M.A. (2004). First isolation and molecular characterization of Ehrlichia canis in Spain. Vet. Parasitol., 125: 365-372.

4. Anderson B.E.; Sumner, J.W.; Dawson, J.E.; Tzianabos, T.; Greene, C.R.; Olson, J.G.; Fishbein, D.B.; Olsen-Rasmussen, M.; Holloway, B.P.; George, E.H. (1992). Detection of the etiologic agent of human ehrlichiosis by polymerase chain reaction. J. Clin. Microbiol., 30: 775-780.

5. Breitschwerdt, E.B.; Hegarty, B.C.; Hancock, S.I. (1998). Sequential evaluation of dogs naturally infected with Ehrlichia canis, Ehrlichia chaffeensis, Ehrlichia equi, Ehrlichia ewingii or Bartonella vinsoni. J. Clin. Microbiol., 36: 2645-2651.

6. Bulla, C.; Takahira, R.K.; Araujo, Jr.J.P.; Trinca, L.A.; Lopes, R.S.; Weidmeyer, C.E. (2004). The relationship between the degree of thrombocytopenia and infection with Ehrlichia canis in an endemic area. Vet. Res., 35: 141-146.

7. Cohn, L.A. (2003). Ehrlichiosis and related infections. Vet. Clin. North Am. Small Anim. Pract., 33: 863-884.

8. Costa, J.O.; Silva, M.; Batista, Jr.J.A.; Guimarães, M.P. (1973). Ehrlichia canis infection in dogs in Belo Horizonte - Brazil. Arq. Esc. Vet., 25: 199-200. 
9. Dagnone, A.S.; Autran, H.S.M.; Vidotto, M.C.; Jojima, F.S.; Vidotto, O. (2003). Ehrlichiosis in anemic, thrombocytopenic, or tick-infested dogs from a hospital population in south Brazil. Vet. Parasitol., 117: 285-290.

10. Doyle, C.K.; Labruna, M.B.; Breitschwerdt, E.B.; Tang, Y.; Corstvet, R.E.; Hegarty, B.C.; Bloch, K.C.; Li, P.; Walker, D.H.; McBride, J.W. (2005). Detection of medically important Ehrlichia by quantitative multicolor TaqMan real-time PCR of the $d s b$ Gene. $J$. Mol. Diagn., 7: 504-510.

11. Dumler, J.S.; Barbet, A.F.; Bekker, C.P.J.; Dasch, G.A.; Palmer, G.H.; Ray, S.C.; Rikihisa, Y.; Rurangirwa, F.R. (2001). Reorganization of genera in the families Rickettsiaceae and Anaplasmataceae in the order Rickettsiales: unification of some species of Ehrlichia with Anaplasma, Cowdria with Ehrlichia and Ehrlichia with Neorickettsia, descriptions of six new species combinations and designation of Ehrlichia equi and HGE agent as subjective synonyms of Ehrlichia phagocytophila. Int. J. Syst. Evol. Microbiol., 51: 2145-2165.

12. Iqbal, Z.; Rikihisa, Y. (1994). Reisolation of Ehrlichia canis from blood and tissues of dogs after doxycycline treatment. J. Clin. Microbiol., 32: 1644-1649.

13. Labarthe, N.; Campos Pereira, M.; Balbarini, O.; Mckee, W.; Coimbra, C.A.; Hoskins, J. (2003). Serologic prevalence of Dirofilaria immintis, Ehrlichia canis and Borrelia burgdorferi infection in Brazil. Vet. Ther., 4: 67-75.

14. Labruna, M.B.; Pereira, M.C. (2001). Carrapatos em cães no Brasil. Clin. Vet., 30: 24-32.

15. Machado, R.Z. (2004). Ehrlichiose canina. Rev. Bras. Parasitol. Vet., 13: 53-57.
16. Machado, R.Z.; Duarte, J.M.B.; Dagnone, A.S.; Szabó, M.P.J. (2006) Detection of Ehrlichia chaffeensis in Brazilian marsh deer (Blastocerus dichotomus). Vet. Parasitol., 139: 262-266.

17. McBride, J.W.; Yu, X.J.; Walker, D.H. (1999). Molecular cloning of the gene for a conserved major immunoreactive 28-kilodalton protein of Ehrlichia canis: a potential serodiagnostic antigen. Clin. Diag. Lab. Immunol., 6: 392-399.

18. McBride, J.W.; Ndip, L.M.; Popov, V.L.; Walker, D.H. (2002). Identification and functional analysis of an immunoreactive DsbAlike thio-disulfide oxidoreductase of Ehrlichia spp. Infect. Immun., 70: 2700-2703.

19. Ndip, L.M.; Ndip, R.N.; Esemu, S.N.; Dickmu, V.L.; Fokam, E.B.; Walker, D.H.; McBride, J.W. (2005). Ehrlichial infection in Cameroonian canines by Ehrlichia canis and Ehrlichia ewingii. Vet. Microbiol., 111: 59-66.

20. Paddock, C.D.; Sumner, J.W.; Shore, G.M.; Bartley, D.C.; Elie, R.C.; McQuade, J.G.; Martin, C.R.; Goldsmith, C.S.; Childs, J.E. (1997) Isolation and characterization of Ehrlichia chaffeensis strain from patients with fatal ehrlichiosis. J. Clin. Microbiol., 35: 2496-2502.

21. Trapp, S.M.; Dagnone, A.S.; Vidotto, O.; Freire, R.L.; Amude, A.M.; Morais, H.S.A. (2006). Seroepidemiology of canine babesiosis and ehrlichiosis in a Hospital population. Vet. Parasitol., 140: 223-230.

22. Torres, H.M.; Massard, C.L.; Figueiredo, M.J.; Ferreira, T.; Almosny, N.R.P. (2002). Isolamento e propagação da Ehrlichia canis em células DH82 e obtenção de antígeno para a reação de imunofluorescência indireta. Rev. Bras. Ciênc. Vet., 9: 77-82.

23. Yu, X.J.; McBride, J.E.; Walker, D.H. (2007). Restriction and expansion of Ehrlichia strain diversity. Vet. Parasitol., 143: 337-346. 